\title{
Optimization and Modelling of Chemical Oxygen Demand Removal by ANAMMOX Process Using Response Surface Methodology
}

\author{
Ali Jalilzadeh, ${ }^{1,2}$ Ramin Nabizadeh, ${ }^{1,2}$ Alireza Mesdaghinia, ${ }^{1,2}$ Aliakbar Azimi, ${ }^{3}$ \\ Simin Nasseri, ${ }^{1,2}$ Amir Hossein Mahvi, ${ }^{1,2}$ and Kazem Naddafi ${ }^{1,2}$ \\ ${ }^{1}$ Department of Environmental Health Engineering, School of Public Health, Tehran University of Medical Sciences, \\ P.O. Box 14155-6446, Tehran, Iran \\ ${ }^{2}$ Centre for Environmental Research, Tehran University of Medical Sciences, Tehran, Iran \\ ${ }^{3}$ Department of Environmental Engineering, Graduate School of the Environment, University of Tehran, Tehran, Iran
}

Correspondence should be addressed to Ramin Nabizadeh; rnabizadeh@tums.ac.ir

Received 4 May 2013; Accepted 18 July 2013

Academic Editor: Athanasios Katsoyiannis

Copyright (c) 2013 Ali Jalilzadeh et al. This is an open access article distributed under the Creative Commons Attribution License, which permits unrestricted use, distribution, and reproduction in any medium, provided the original work is properly cited.

\begin{abstract}
A systematic model for chemical oxygen demand (COD) removal using the ANAMMOX (Anaerobic AMMonium OXidation) process was provided based on an experimental design. At first, the experimental data was collected from a combined biological aerobic/anaerobic reactor. For modelling and optimization of COD removal, the main parameters were considered, such as COD loading, ammonium, $\mathrm{pH}$, and temperature. From the models, the optimum conditions were determined as COD $97.5 \mathrm{mg} / \mathrm{L}$, ammonium concentration equal to $28.75 \mathrm{mg}-\mathrm{N} / \mathrm{L}, \mathrm{pH} 7.72$, and temperature $31.3^{\circ} \mathrm{C}$. Finally, the analysis of the optimum conditions, performed by the response surface method, predicted COD removal efficiency of $81.07 \%$ at the optimum condition.
\end{abstract}

\section{Introduction}

The Anaerobic AMMonium OXidation (ANAMMOX) process is introduced as a novel and low cost alternative to conventional nitrogen removal systems to treat nitrogenous compounds [1]. Van de Graaf evaluated the pathway of metabolic Candidatus Brocadia anammoxidans and Strous suggested a different metabolic course for the nitrogen cycle. In both studies, hydrazine was the most important intermediate [2-4].

Detection studies of $16 \mathrm{~S}$ rDNA sequences demonstrated that the planctomycete bacteria, such as Brocadia anammoxidans, Kuenenia stuttgartiensis, are found in ANAMMOX conditions [5].

ANAMMOX bacteria oxidize ammonium under anoxic conditions, and in this reaction nitrite acts as the electron acceptor based on the following equation [1]:

$$
\begin{aligned}
& \mathrm{NH}_{4}{ }^{+}+1.32 \mathrm{NO}_{2}{ }^{-}+0.066 \mathrm{HCO}_{3}{ }^{-}+0.13 \mathrm{H}^{+} \\
& \longrightarrow 0.066 \mathrm{CH}_{2} \mathrm{O}_{0.5} \mathrm{~N}_{0.15}+1.02 \mathrm{~N}_{2} \\
& +0.26 \mathrm{NO}_{3}{ }^{-}+2.03 \mathrm{H}_{2} \mathrm{O}
\end{aligned}
$$

During the ANAMMOX process, the highest removal efficiency of ammonium and nitrite was up to 97 and 98\%, respectively [6]. Molinuevo showed that ANAMMOX and denitrification always occurred simultaneously, meaning that both processes could coexist in the same environment [7]. They mentioned that environmental conditions such as $\mathrm{COD}$, nitrite, nitrate, ammonium, $\mathrm{pH}$, and temperature have to be controlled to provide the appropriate balance between ANAMMOX and denitrification communities. It was reported that, during the ANAMMOX process, 


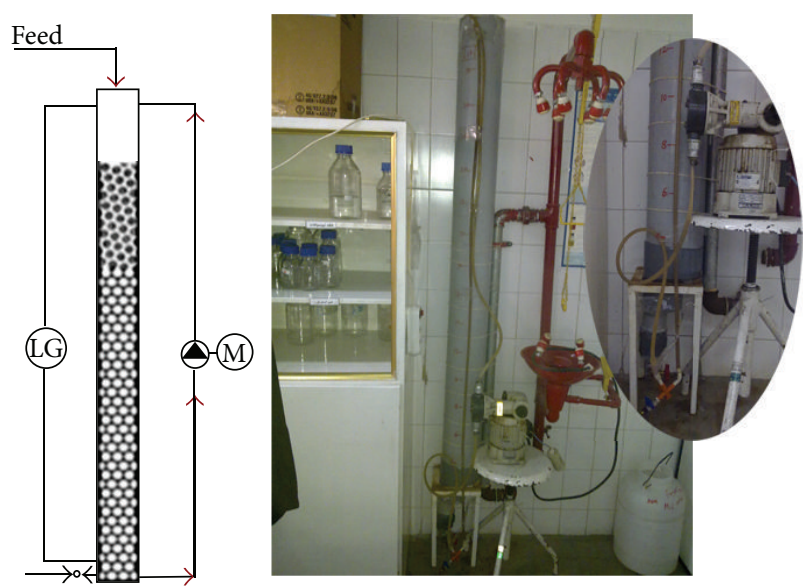

FIgURE 1: Start-up pilot.

the highest removal efficiency of ammonium and nitrite was up to 97 and $98 \%$, respectively [6].

In comparison to the conventional nitrification-denitrification process, ANAMMOX consumes 100\% less biodegradable organic carbon and at least 50\% less oxygen and has lower operating costs [8].

In this work, we used ANAMMOX to eliminate the chemical oxygen demand (COD) content. Typical range of $\mathrm{COD}$ concentration in untreated municipal wastewater is $250-800 \mathrm{mg} / \mathrm{L}$, while value of this parameter is more in supernatant or industrial wastewater than municipal wastewater [9].

The objective of the present study was to optimize COD removal efficiency with parameters such as ammonium, $\mathrm{pH}$, and temperature. Evaluation of the COD removal and modelling the removal efficiency during the ANAMMOX process were performed using the response surface methodology (RSM). As there are few reports about optimum conditions for the elimination of COD in this process, we tried to determine the optimum conditions for COD removal through the novel modelling approach.

\section{Material and Methods}

2.1. Pilot Study. In this study, two different pilots have been used as described below.

2.1.1. Start-Up Pilot. As shown in Figure 1, this pilot was used to extract ANAMMOX bacteria from activated sludge to be used in the other pilot. The start-up pilot was operated in batch conditions to enrich ANAMMOX biomass. This pilot used PVC because the nonpolar molecular structure of PVC does not allow it to react against polar water molecules and other soluble materials used in this study. Also, PVC is a suitable heat barrier and could prevent changes in the reactor temperature which has been proved to be a hindering factor in ANAMMOX bacteria growth. The reactor was $15 \mathrm{~cm}$ in diameter and $170 \mathrm{~cm}$ high, yielding an active volume of 30 litres to provide plug flow conditions. Arbitrary flow inclined to plug flow when dispersion number 0.1 prevailed.

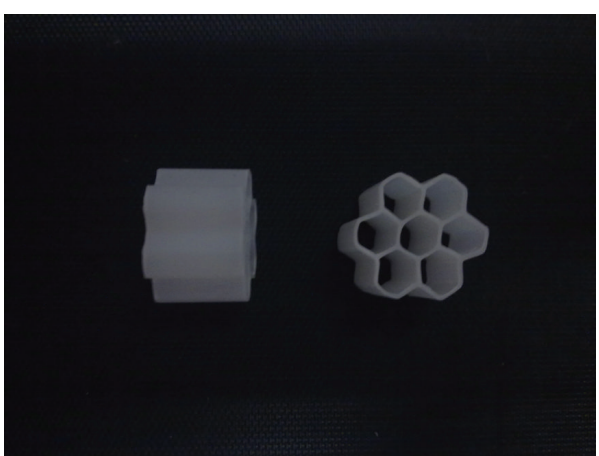

Figure 2: Growth media used in this study, model: BC-800.

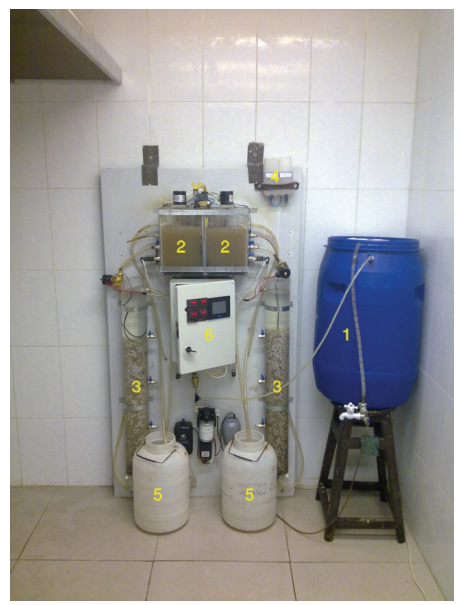

FIGURE 3: Units of reaction pilot: 1-feed tank, 2-aeration tank (SHARON, Single reactor system for High activity Ammonium Removal Over Nitrite), 3-ANAMMOX reactor, 4- $\mathrm{pH}$ adjustment tanks, 5-effluent tank, 6-PLC system.

The suspended growth media used inside the reactor was model BC, manufactured by the Abzian Nil Company, with specific surface area of $800 \mathrm{~m}^{2} / \mathrm{m}^{3}$. Figure 2 shows a sample of this media. A diaphragm pump, made by Jessco, Germany, no. MB 140 02/1, was used to provide circulation in the reactor.

2.1.2. Reaction Pilot. As shown in Figure 3, the reactor used was the main combined biological aerobic/anaerobic reactor consisting of the following parts: a synthetic 100-litre wastewater tank made of poly-Ethylene and an 8 millimetre plastic level gage installed on the tank. It took between 1 and 3 days to empty the tank depending on the flow rate. In order to avoid microbial growth and possible change in the organic and nutrient concentration of the synthetic wastewater, the tank was washed and disinfected weekly using $5 \%$ chlorine solution.

Wastewater was transferred to the pilot using a diaphragm pump with a 1.2 litre per minute capacity and $2 \mathrm{~atm}$. Two hand operated flow-meters (between 16 and $160 \mathrm{~mm} / \mathrm{min}$ ) adjusted the wastewater flow rates. The first part of the processing of the main pilot comprised two 10 
TABLE 1: The composition of the mineral medium.

\begin{tabular}{|c|c|c|c|c|c|}
\hline Trace element & $\mathrm{mg} / \mathrm{kg}_{\mathrm{COD}}$ & Nutrients for main pilot & $\mathrm{g} / \mathrm{L}$ & Nutrients for start-up pilot & $\mathrm{g} / \mathrm{L}$ \\
\hline $\mathrm{Al}_{2}\left(\mathrm{SO}_{4}\right)_{3}, 2 \mathrm{H}_{2} \mathrm{O}$ & 1.9 & $\mathrm{NH}_{4} \mathrm{Cl}$ & 1.383 & $\mathrm{NH}_{4} \mathrm{Cl}$ & 0.3 \\
\hline $\mathrm{CaCl}_{2}, 6 \mathrm{H}_{2} \mathrm{O}$ & 693.8 & $\mathrm{C}_{6} \mathrm{H}_{12} \mathrm{O}_{6}$ & 0.156 & $\mathrm{NaHCO}_{3}$ & 0.07 \\
\hline $\mathrm{CoCl}_{2}$ & 4.02 & $\mathrm{KH}_{2} \mathrm{PO}_{4}$ & 0.07 & $\mathrm{NaNO}_{2}$ & 0.15 \\
\hline $\mathrm{CuCl}_{2}$ & 0.6 & $\mathrm{NaHCO}_{3}$ & 2.16 & & \\
\hline $\mathrm{FeCl}_{3}, 6 \mathrm{H}_{2} \mathrm{O}$ & 482.1 & & & & \\
\hline $\mathrm{MgSO}_{4}, 7 \mathrm{H}_{2} \mathrm{O}$ & 2563.5 & & & & \\
\hline $\mathrm{MnSO}_{4}, \mathrm{H}_{2} \mathrm{O}$ & 3.1 & & & & \\
\hline$\left(\mathrm{NH}_{4}\right)_{6} \mathrm{Mo}_{7} \mathrm{O}_{24}, \mathrm{H}_{2} \mathrm{O}$ & 0.2 & & & & \\
\hline $\mathrm{NiCl}_{2}, 6 \mathrm{H}_{2} \mathrm{O}$ & 2 & & & & \\
\hline $\mathrm{ZnCl}_{2}$ & 6.3 & & & & \\
\hline EDTA & 0.006 & & & & \\
\hline
\end{tabular}

litre transparent Plexiglas aerobic tanks in which suspended heterotrophic aerobic microorganisms were grown.

An aerobic section tank $20 \mathrm{~cm}$ wide and long and $25 \mathrm{~cm}$ high was chosen in order to provide conditions of complete mix. The above dimensions provided arbitrary conditions inclined to a complete mix with a dispersion number of over 4. Solenoid inlet and outlet valves had diameters of 6 and 8 millimetres, respectively. A manual brass butterfly sampling valve with a diameter of $3 / 8$ inches was installed. Mixed liquor inside the aerobic reactor was constantly agitated by the diffused aerator and mixer providing the required oxygen. Electric heat elements were installed in each tank. These elements could manually adjust the heat between 20 and 35 degrees centigrade. In the first phase of operating the reactor, the wastewater would enter an up-flow sedimentation tank. The diameter of the sedimentation tank was $8 \mathrm{~cm}$ and its general height was $25 \mathrm{~cm}$.

The second phase of the process used a 10-litre anaerobic ANAMMOX cylinder tank (diameter $10 \mathrm{~cm}$ and effective height $100 \mathrm{~cm}$ ). This tank was filled with fixed media of $800 \mathrm{~m}^{2} / \mathrm{m}^{3}$ specific surface area made by the Abzian Nil Company (model BC). The media was first kept in the startup pilot for 6 months and was covered by ANAMMOX bacteria. For sampling, four $3 / 8$ inch brass butterfly valves were installed on the reactor, 25 centimetres apart. Like the aerobic tank, the heat was adjusted in this reactor using electric elements in each tank. The $\mathrm{pH}$ (between 7 and 9) was one of the other main variants studied. To adjust the $\mathrm{pH}$ in the tank, the following steps were taken: in the beginning, the $\mathrm{pH}$ was measured by an online measuring device; then, the $\mathrm{pH}$ was measured through a $\mathrm{pH}$ transmitter sensor, made by Lutron, Taiwan no. TR-PHT1A4, and compared with the specific amount for the tank by using the programmable logic control (PLC) system made by Siemens, Germany. In cases of deviation in amounts of up to 0.2 units, one of the solenoid valves on the aerobic tank that were connected to acid and alkaline solutions would open, allowing 3-4 drops of $0.5 \%$ solution of either acid or alkaline into the tank. After one minute, the above steps were repeated automatically until the $\mathrm{pH}$ of the tank reached the desired specific amount for the study.
Return sludge from a well-operated wastewater treatment unit in Tehran was used for seeding the reactors. Since two separate reactors were used in this study, start-up and seeding methods for each are explained individually. Initially, sludge from the wastewater treatment unit was added to the startup reactor. After seeding, the system was operated in batch conditions for adaptation and biofilm formation for a period of 5 months.

At the start-up process, $40 \mathrm{mg}-\mathrm{N} / \mathrm{L}$ ammonium chloride as the ammonium source and $60 \mathrm{mg}-\mathrm{N} / \mathrm{L}$ sodium nitrate as the nitrate source were used in the inflow. The ratio of nitrite to ammonium was considered to be 1.5. Sodium bicarbonate was used with $50 \mathrm{mg} / \mathrm{L}$ as the alkaline source of the reactor. In this study, the ratio of bicarbonate to ammonium was chosen to be 1.2. At this stage, to monitor the performance of the nitrate system, nitrite, EC, $\mathrm{pH}$, and alkalinity were the parameters observed.

For seeding and start-up of the main reactor, aerobic sludge was provided from the wastewater treatment unit. The sludge required for the anaerobic section (ANAMMOX) was taken from the start-up reactor made for this purpose. After seeding the aerobic reactor, the pilot was operated with continuous flow for another month for adaptation of the mixed liquor with the environment, enrichment of the microbial population, and co-ordination between the qualitative and quantitative sections of the aerobic and anaerobic reactor. In this study, the ammonium to nitrite ratio was 1.5 and ammonium to bicarbonate ratio was 1.2 in the inlet flow of the reaction pilot.

The constituents of synthetic wastewater, which was prepared on laboratory scales, are presented in Table 1. All reagents provided were of analytical grade from the Merck and Sigma Company. Heterotroph and autotroph bacteria in the reactor were responsible for COD removal and oxidation of the ammonium simultaneously. ANAMMOX microorganisms in the anaerobic autotroph section need nitrite for their growth in addition to ammonium. In this reactor, partial oxidation of ammonium (nitritation) occurred in the aerobic section. Therefore, the inflow only contained COD and ammonium.

Throughout the experiments, the inflow ammonium concentration varied between $40 \mathrm{mg}-\mathrm{N} / \mathrm{L}$ and $120 \mathrm{mg}-\mathrm{N} / \mathrm{L}$. 
TABLE 2: The natural and coded parameters.

\begin{tabular}{lccccccc}
\hline $\begin{array}{l}\text { Natural } \\
\text { factors }\end{array}$ & $\begin{array}{c}\text { Coded } \\
\text { factors }\end{array}$ & Unit & $\begin{array}{c}\text { Low axial } \\
(-\alpha=-2)\end{array}$ & $\begin{array}{c}\text { Low factorial } \\
(-1)\end{array}$ & $\begin{array}{c}\text { Centre point } \\
(0)\end{array}$ & $\begin{array}{c}\text { High factorial } \\
(+1)\end{array}$ & $\begin{array}{c}\text { High axial } \\
(+\alpha=+2)\end{array}$ \\
\hline $\mathrm{COD}$ & $x_{1}$ & $\mathrm{mg} / \mathrm{L}$ & 40 & 97.5 & 155 & 212.5 & 270 \\
$\mathrm{NH}_{4}{ }^{+}$ & $x_{2}$ & $\mathrm{mg}-\mathrm{N} / \mathrm{L}$ & 25 & 28.75 & 32.5 & 36.25 & 40 \\
$\mathrm{Temp}$. & $x_{3}$ & ${ }^{\circ} \mathrm{C}$ & 20 & 23.75 & 27.5 & 31.25 & 35 \\
$\mathrm{pH}$ & $x_{4}$ & - & 6.5 & 7.05 & 7.6 & 8.15 & 8.7 \\
\hline
\end{tabular}

TABLE 3: The CCD using the coded factors.

\begin{tabular}{|c|c|c|c|c|}
\hline Run & $\mathrm{COD}$ & $\mathrm{NH}_{4}^{+}$Inf. & Temp. & $\mathrm{pH}$ \\
\hline 1 & 0 & 0 & 2 & 0 \\
\hline 2 & 1 & 1 & -1 & -1 \\
\hline 3 & 1 & 1 & -1 & 1 \\
\hline 4 & 0 & 0 & 0 & 0 \\
\hline 5 & 0 & 2 & 0 & 0 \\
\hline 6 & -1 & 1 & -1 & 1 \\
\hline 7 & 0 & 0 & 0 & 0 \\
\hline 8 & -2 & 0 & 0 & 0 \\
\hline 9 & -1 & -1 & -1 & -1 \\
\hline 10 & 0 & 0 & 0 & 0 \\
\hline 11 & -1 & -1 & 1 & 1 \\
\hline 12 & 1 & -1 & -1 & -1 \\
\hline 13 & -1 & -1 & -1 & 1 \\
\hline 14 & 1 & 1 & 1 & 1 \\
\hline 15 & 0 & 0 & 0 & 0 \\
\hline 16 & 1 & 1 & 1 & -1 \\
\hline 17 & -1 & 1 & 1 & -1 \\
\hline 18 & 0 & -2 & 0 & 0 \\
\hline 19 & -1 & -1 & 1 & -1 \\
\hline 20 & 0 & 0 & 0 & 2 \\
\hline 21 & 0 & 0 & 0 & -2 \\
\hline 22 & 2 & 0 & 0 & 0 \\
\hline 23 & 1 & -1 & 1 & 1 \\
\hline 24 & -1 & 1 & -1 & -1 \\
\hline 25 & 1 & -1 & -1 & 1 \\
\hline 26 & 1 & -1 & 1 & -1 \\
\hline 27 & -1 & 1 & 1 & 1 \\
\hline 28 & 0 & 0 & 0 & 0 \\
\hline 29 & 0 & 0 & 0 & 0 \\
\hline 30 & 0 & 0 & -2 & 0 \\
\hline
\end{tabular}

Ammonia, nitrogen, and phosphorus were added to the inflow using $\mathrm{NH}_{4} \mathrm{CL}$ and $\mathrm{NaH}_{2} \mathrm{PO}_{4}$. Other trace elements for microbial growth were provided by a stock solution of the trace element and were $1 \mathrm{~mL}$ in every 10 litres of the inflow $(0.01 \% \mathrm{~V} / \mathrm{V})$. Concentrations of the elements in the trace element stock solution are explained in Table 1.

2.2. Analytical Techniques. Soluble COD, nitrite, ammonium, and $\mathrm{pH}$ were analysed according to procedures 5220-C, $4500-\mathrm{NO}_{2}{ }^{-} \mathrm{B}, 4500-\mathrm{NH}_{3} \mathrm{C}$, and $4500-\mathrm{H}^{+} \mathrm{B}$, respectively (American Public Health Association (APHA) 2005). For
TABLE 4: Design summary for model of COD removal in SBR.

\begin{tabular}{lccccccc}
\hline Response & Name & Units & Analysis & Min & Max & Mean & Model \\
\hline$Y_{1}$ & $\begin{array}{c}\text { COD } \\
\text { removal }\end{array}$ & $\%$ & Polynomial & 29 & 89 & 66.43 & Quadratic \\
\hline
\end{tabular}

measurement of nitrite a Lambda 25, PerkinElmer Inc., USA was used. The $\mathrm{pH}$ measurements were performed using a $\mathrm{pH}$ meter, model $827 \mathrm{pH}$ lab, Metrohm, Switzerland.

2.3. Response Surface Methodology (RSM). RSM includes the collection of the mathematical and statistical methods for modelling and determining the model equations. The desired response is a function of several variables. RSM is a branch of experimental design and the purpose of its application was optimization of the responses of the experiments and number of tests. As a first step, we found a suitable approximate function between the responses and the set of independent variables. This was a polynomial function of independent variables. The behaviour of the system is explained by the following quadratic equation $[10,11]$ :

$$
y=\beta_{0}+\sum_{i=1}^{k} \beta_{1} x_{1}+\sum_{i=1}^{k} \beta_{i i} x_{i}^{2}+\sum_{i=1}^{k} \sum_{j=1}^{k} \beta_{i j} x_{i} x_{j}+\epsilon
$$

where $y$ is the response, $\beta_{0}, \beta_{1}, \beta_{i i}, \beta_{i j}$ are the regression coefficients, $\epsilon$ is the error value, and $X_{j}$ coded variables of the system.

The least square method was used to determine the polynomial approximation. Central composite design (CCD) was used to fit this model. Table 2 illustrates the CCD for the natural and coded parameters (as $x_{1}$ : COD, $x_{2}$ : ammonium concentration, $x_{3}$ : temperature, and $\left.x_{4}: \mathrm{pH}\right)$. In the CCD, for each coded factor (Table 2), low axial, high axial and factorial and a central point were coded as $-2,-1,0,+1$, and +2 , respectively. The analysis range was from low axial to high axial and the ranges for $x_{1}, x_{2}, x_{3}$, and $x_{4}$ are considered to be $40-270,25-40,20-35$, and 6.5-8.7, respectively.

\section{Results and Discussions}

3.1. Analysis of Variance. Using the experimental design method, 30 runs were considered for modelling and optimization of the parameters. Table 3 shows the runs of experiments with coded factors using the CCD. The response of COD removal indicated as $Y_{1}$, along with other details, is displayed in Table 4. This table includes the design summary 
TABLE 5: ANOVA for RSM (ANOVA table).

\begin{tabular}{lcccc}
\hline Source & Mean square & $F$-value & $P$ value & \\
\hline COD removal & 6780.92 & 6.46 & 0.0003 & Significant \\
model & 4082.04 & 42.81 & $<0.0001$ & \\
$x_{1}$ & 84.38 & 0.88 & 0.3593 & \\
$x_{2}$ & 759.38 & 7.96 & 0.0113 & \\
$x_{3}$ & 210.04 & 2.2 & 0.1551 & \\
$x_{4}$ & 76.56 & 0.8 & 0.3821 & \\
$x_{1} x_{3}$ & 95.06 & 1 & 0.3313 \\
$x_{1} x_{4}$ & 33.06 & 0.35 & 0.5633 \\
$x_{2} x_{4}$ & 1.56 & 0.016 & 0.8996 \\
$x_{3} x_{4}$ & 12.56 & 0.13 & 0.7209 \\
$x_{1}^{2}$ & 578.31 & 6.06 & 0.0241 & \\
$x_{3}^{2}$ & 1023.06 & 10.73 & 0.0042 & \\
$x_{4}^{2}$ & 1716.45 & & & \\
Residual & 1710.95 & 119.65 & $<0.0001$ & \\
Lack of fit & 5.5 & & & \\
Pure error & 8497.37 & & & \\
Cortotal & & &
\end{tabular}

of COD removal in the SBR reactor. According to this table, a quadratic model and polynomial analysis were used for the final modelling. Table 5 shows the analysis of variance (ANOVA) for experimental data. The ANOVA table provides the $P$ value, $F$-value, and mean square for the COD removal model and other variances (such as coded factor) and their interactions. The $P$ value for the model with $95 \%$ statistical probability $(<0.0003)$ is significant. Also, the statistical values such as lack of fit, pure error, and Cor total (sum of squares total corrected for the mean) are presented. Figure 4 shows the experimental and model data obtained in the design and model conditions. The design and model data were prepared based on the experimental and COD removal model in the following equation:

$$
\begin{aligned}
\mathrm{COD}_{\text {Removal\% }}= & 75.44-13.04 x_{1}-1.88 x_{2}-5.63 x_{3} \\
& -2.96 x_{4}-2.19 x_{1} x_{3}-2.44 x_{1} x_{4}+1.44 x_{2} x_{4} \\
& +0.31 x_{3} x_{4}-0.67 x_{1}^{2}-4.54 x_{3}^{2}-6.04 x_{4}^{2} .
\end{aligned}
$$

In the next step, statistical values of the quadratic model were determined. Table 6 shows $R$-squared, adjusted $R$ squared, mean, C.V.\%, and so forth. Based on statistical values, the multiple correlation coefficient. Adjusted $R$ squared, predicted $R$-squared, coefficient of variation, and the mean removal efficiency were $0.81,0.68,0.64,14.7 \%$, and $66.43 \%$, respectively.

3.2. Interaction of Main Parameters. Figure 5 displays the contour response surface plot of the interaction between the natural variables for COD removal efficiency. Figure 5(a) illustrates the interaction of the reactor temperature and COD load on COD removal efficiency. According to the

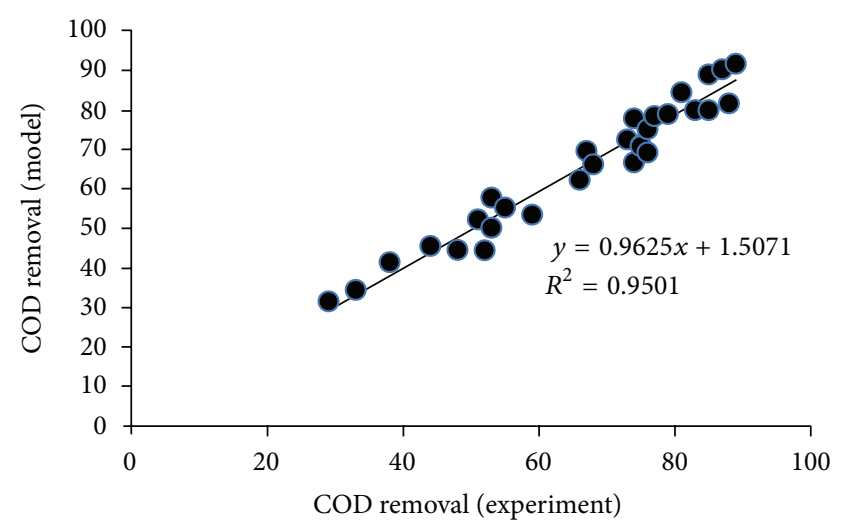

FIGURE 4: COD removal efficiency computed by the model versus the experimental COD removal efficiency.

TABLE 6: Statistical values for obtained removal data.

\begin{tabular}{lc}
\hline$R$-squared & 0.81 \\
Adj $R$-squared & 0.68 \\
Pred $R$-squared & 0.64 \\
Adeqprecision & 9.883 \\
Std. Dev. & 9.77 \\
Mean & 66.43 \\
C.V.\% & 14.7 \\
PRESS & 6638.89 \\
\hline
\end{tabular}

${ }^{*}$ Predicted residual sum of squares of model.

plot, it is obvious that the higher efficiency occurred in COD amounts lower than $100 \mathrm{mg} / \mathrm{L}$ and temperature ranges between 20 and $35^{\circ} \mathrm{C}$.

In this temperature range, $26^{\circ} \mathrm{C}$ yields the more desirable model response. Also, increasing the COD load is associated with higher COD content in the effluent flow. Jianlong successfully used an EGSB (Expanded Granular Sludge Bed) reactor to obtain COD removal efficiency of about $84.4 \%$ on $500 \mathrm{mg} / \mathrm{L}$ of initial concentrations and $37^{\circ} \mathrm{C}$ [12]. Molinuevo reported about $51 \%$ reduction efficiency acquired during the ANAMMOX process with $5 \mathrm{~g} / \mathrm{L}$ initial concentration of COD and Hellinga believe that the two groups of bacteria, including ammonium and nitrite oxidation bacteria, are sensitive to environmental temperature, and that higher temperatures $\left(35-38^{\circ} \mathrm{C}\right)$ facilitate oxidation of ammonium [7, 13]. Also, Yamamoto successfully demonstrated that nitration occurred with temperatures in the range of $15-30^{\circ} \mathrm{C}$ [14].

Table 7 shows the COD elimination percentages in different studies in comparison with the results of the present research. The effects of $\mathrm{pH}$ and COD load in COD removal have been shown in Figure 5(b). Comparing Figures 5(a) and 5(b) reveals that $\mathrm{pH}$ and temperature effectiveness in COD removal follow a similar pattern. Therefore, according to the results obtained, $\mathrm{pH}$ and temperature are the most prominent parameters in COD elimination in ANAMMOX reactors.

$\mathrm{pH}$ ranges between 7 and 8.5 provide better conditions for the biodegradation of COD. COD removal efficiency was obtained at above $90 \%$ in both Figures 5(a) and 5(b). 


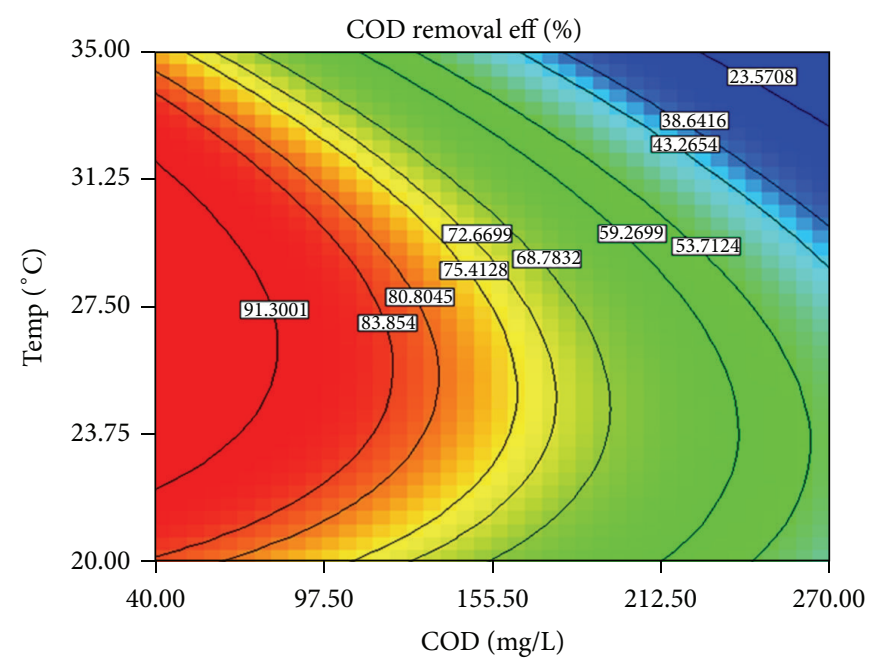

(a)

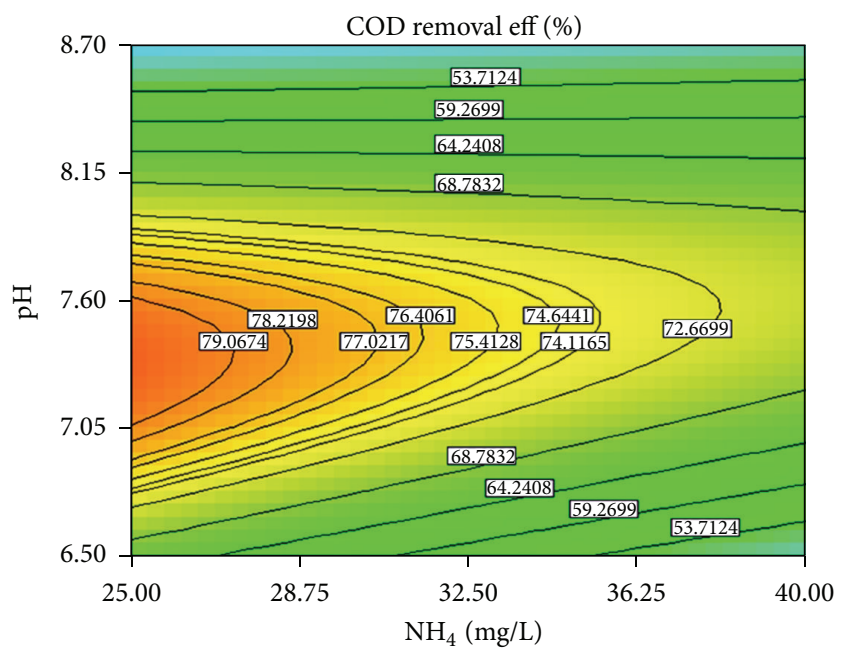

(c)

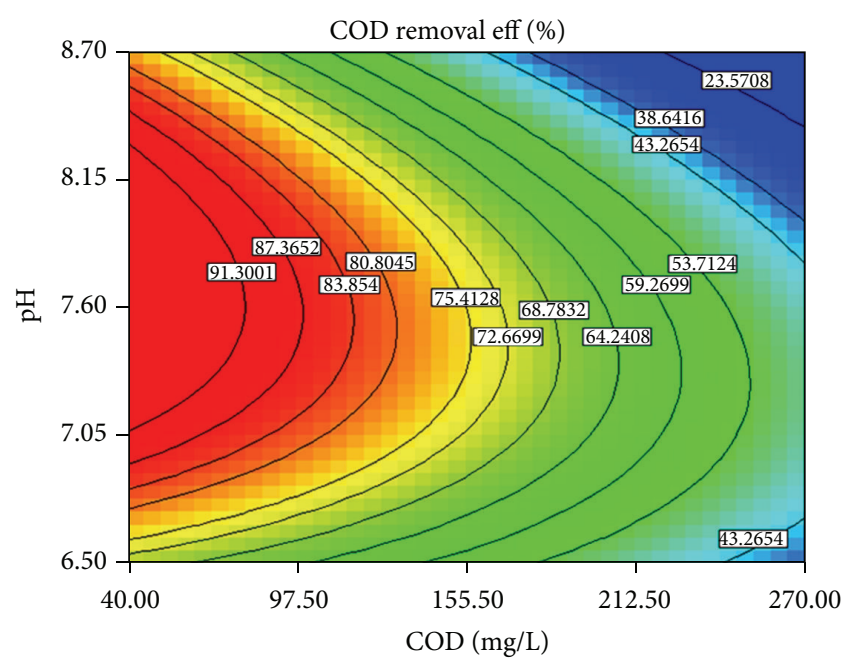

(b)

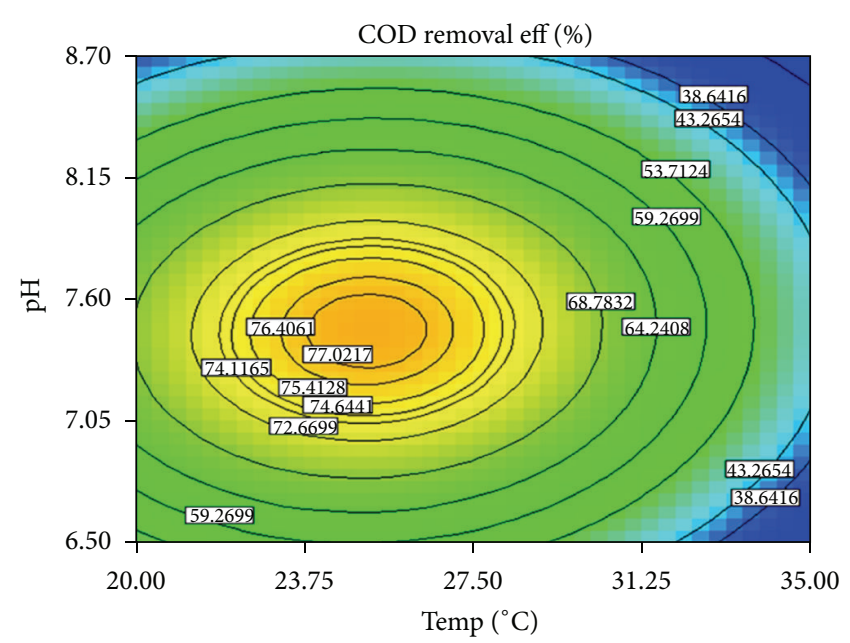

(d)

FIGURE 5: Contour diagram of natural variables for COD removal efficiency.

TABLE 7: Performed studies of COD removal using the ANAMMOX process.

\begin{tabular}{lccc}
\hline Reactor & Type of wastewater & COD removal efficiency & Reference \\
\hline SBR & Synthetic & $81.07 \%$ model, $76.6 \%$ experimental & Present Study \\
SBR & Synthetic & $82.6 \%$ & {$[15]$} \\
UASB & Piggery manure & $51 \%$ & {$[6]$} \\
up-flow fixed-bed & Swine wastewater digester liquor & $25 \pm 10 \%$ & {$[16]$} \\
EGSB & Brewery wastewater & $84 \%$ & {$[8]$} \\
NRBC & Synthetic & $70 \%$ & {$[17]$} \\
SBR & Sanitary landfill leachate & $20-30 \%$ & {$[18]$} \\
\hline
\end{tabular}

Egli reported that the role of $\mathrm{pH}$ is more important than temperature in ammonium oxidizing bacteria subgroups such as Nitrosomonas and Nitrosomonas europaea, and $\mathrm{pH}$ can be used as a controlling tool for operating conditions. The desirable conditions for these bacteria are $\mathrm{pH} 7.5$ and $30^{\circ} \mathrm{C}$ $[19,20]$.
Figure 5(c) displays the interactions of $\mathrm{pH}$ and the influent of ammonium. The amount of ammonium produced due to biological consumption is a significant factor in COD bioremoval. According to the trend of removal efficiency, it can be found that the COD can be removed if the reactor's $\mathrm{pH}$ is kept in proper points. These points range between 
TABLE 8: The optimum conditions.

\begin{tabular}{lccccc}
\hline $\begin{array}{l}\mathrm{COD} \\
\mathrm{mg} / \mathrm{L}\end{array}$ & $\begin{array}{c}\mathrm{NH}_{4 . \mathrm{in}} \\
\mathrm{mg}-\mathrm{N} / \mathrm{L}\end{array}$ & $\begin{array}{c}\text { Temp. } \\
{ }^{\circ} \mathrm{C}\end{array}$ & $\begin{array}{c}\mathrm{pH} \\
-\end{array}$ & $\begin{array}{c}\mathrm{COD} \\
\text { removal eff. } \\
\text { model }\end{array}$ & $\begin{array}{c}\text { COD } \\
\text { removal eff. } \\
\text { experimental }\end{array}$ \\
\hline 97.5 & 28.75 & 31.3 & 7.72 & 81.07 & 76.6 \\
\hline
\end{tabular}

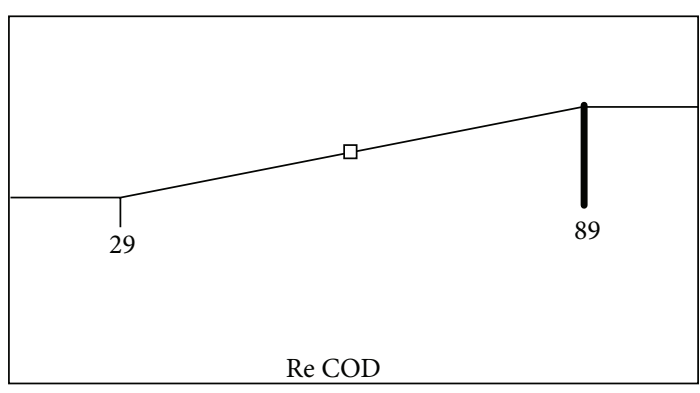

FIGURE 6: Rams functions and optimal solution.

7 and 8. Therefore, $\mathrm{pH}$ is important in controlling COD removal in ANAMMOX. The final interaction indicates two important parameters: the $\mathrm{pH}$ and temperature (Figure 5(d)). Among the controlling parameters for bacterial and biological growth, $\mathrm{pH}$ and temperature are more significant than the others. Hence, desirable rates for these parameters are essential for controlling the ANAMMOX process. Regarding the $d$ plot, the most appropriate COD removal conditions are $\mathrm{pH} 7-8$ and temperatures of $20-30^{\circ} \mathrm{C}$. Decreasing the COD loading can be related to the simultaneous growth of ANAMMOX and denitrification communities. A study reported by Jetten demonstrated the highest activity of ANAMMOX bacteria in $\mathrm{pH} 7-8.5$ and a temperature range of $30-37^{\circ} \mathrm{C}$ [21].

A study reported by Yan and $\mathrm{Hu}$ demonstrated that the maximum COD removal rates were obtained when the temperature and $\mathrm{pH}$ were less than $35^{\circ} \mathrm{C}$ and 8 , respectively [15]. Yamamoto et al. reported the highest COD removal rate in a combined SHARON/ANAMMOX reactor, as high as $69 \%$ in the steady state condition [16]. Chen et al. reported that the optimum $\mathrm{pH}$ and temperature for the ANAMMOX part in the combined CANON/ANAMMOX reactor were $8-8.2$ and $35^{\circ} \mathrm{C}$, respectively [17]. Also, Spagni and MarsiliLibelli found that the maximum COD removal with the ANAMMOX reactor for sanitary landfill leachate was 35\% [18].

3.3. Optimization of COD Removal. At this stage, optimum conditions for higher elimination of COD were determined. An individual desirable function for response (COD removal) at the optimum conditions is shown in Figure 6. The bold line (in Figure 6) indicates the best solution achieved for optimization based on the observed higher removal. Table 8 shows the optimum values with regard to the optimal solution. Under optimum conditions, COD removal efficiency of about $81.07 \%$ was predicted by the model. The suggested parameters were then used under real conditions and the removal efficiency was equal to $76.6 \%$. It is acceptable for the $95 \%$ confidence interval.

\section{Conclusion}

With regard to the present study, it can be shown that the amounts of COD, influent ammonium, $\mathrm{pH}$, and temperature are important parameters for biological functions. Also, RSM as a statistical method can be used in the analysis of experimental data, optimization of considerable factors, and modelling. Based on the experimental data and RSM output, the model of COD removal was determined to be significant with a $P$ value of 0.0003 and $R^{2}$ of 0.81 . The optimum conditions with higher removal efficiency (81.07\%) were found to be COD $97.5 \mathrm{mg} / \mathrm{L}$, influent ammonium $28.75 \mathrm{mg}$ $\mathrm{N} / \mathrm{L}, \mathrm{pH} 7.72$, and temperature $31.3^{\circ} \mathrm{C}$.

\section{Acknowledgment}

The authors acknowledge the support of Tehran University of Medical Sciences and Health Services Grant no. 10919 dated 17-05-2010.

\section{References}

[1] A. Mulder, A. A. van de Graaf, L. A. Robertson, and J. G. Kuenen, "Anaerobic ammonium oxidation discovered in a denitrifying fluidized bed reactor," FEMS Microbiology Ecology, vol. 16, no. 3, pp. 177-184, 1995.

[2] A. A. van de Graaf, P. de Bruijn, L. A. Robertson, M. S. M. Jetten, and J. G. Kuenen, "Metabolic pathway of anaerobic ammonium oxidation on the basis of $15 \mathrm{~N}$ studies in a fluidized bed reactor," Microbiology, vol. 143, no. 7, pp. 2415-2421, 1997.

[3] M. Strous, E. Pelletier, S. Mangenot et al., "Deciphering the evolution and metabolism of an anammox bacterium from a community genome," Nature, vol. 440, no. 7085, pp. 790-794, 2006.

[4] L. Zhang, P. Zheng, C.-J. Tang, and R.-C. Jin, "Anaerobic ammonium oxidation for treatment of ammonium-rich wastewaters," Journal of Zhejiang University B, vol. 9, no. 5, pp. 416-426, 2008.

[5] I. Schmidt, O. Sliekers, M. Schmid et al., "New concepts of microbial treatment processes for the nitrogen removal in wastewater," FEMS Microbiology Reviews, vol. 27, no. 4, pp. 481492, 2003.

[6] Z. Yang, S. Zhou, and Y. Sun, "Start-up of simultaneous removal of ammonium and sulfate from an anaerobic ammonium oxidation (anammox) process in an anaerobic up-flow bioreactor," Journal of Hazardous Materials, vol. 169, no. 1-3, pp. 113-118, 2009.

[7] B. Molinuevo, M. C. García, D. Karakashev, and I. Angelidaki, "Anammox for ammonia removal from pig manure effluents: effect of organic matter content on process performance," Bioresource Technology, vol. 100, no. 7, pp. 2171-2175, 2009.

[8] Y. Tal, J. E. M. Watts, and H. J. Schreier, "Anaerobic ammoniumoxidizing (Anammox) bacteria and associated activity in fixedfilm biofilters of a marine recirculating aquaculture system," Applied and Environmental Microbiology, vol. 72, no. 4, pp. 2896-2904, 2006.

[9] E. Metcalf, Wastewater Engineering: Treatment and Reuse, McGraw-Hill, New York, NY, USA, 2003.

[10] Z. Zaroual, H. Chaair, A. H. Essadki, K. El Ass, and M. Azzi, "Optimizing the removal of trivalent chromium by electrocoagulation using experimental design," Chemical Engineering Journal, vol. 148, no. 2-3, pp. 488-495, 2009. 
[11] T. Ölmez, "The optimization of $\mathrm{Cr}(\mathrm{VI})$ reduction and removal by electrocoagulation using response surface methodology," Journal of Hazardous Materials, vol. 162, no. 2-3, pp. 1371-1378, 2009.

[12] W. Jianlong and K. Jing, "The characteristics of anaerobic ammonium oxidation (ANAMMOX) by granular sludge from an EGSB reactor," Process Biochemistry, vol. 40, no. 5, pp. 19731978, 2005.

[13] C. Hellinga, A. A. J. C. Schellen, J. W. Mulder, M. C. M. van Loosdrecht, and J. J. Heijnen, "The SHARON process: an innovative method for nitrogen removal from ammonium-rich waste water," Water Science and Technology, vol. 37, no. 9, pp. 135-142, 1998.

[14] T. Yamamoto, K. Takaki, T. Koyama, and K. Furukawa, "Novel partial nitritation treatment for anaerobic digestion liquor of swine wastewater using swim-bed technology," Journal of Bioscience and Bioengineering, vol. 102, no. 6, pp. 497-503, 2006.

[15] J. Yan and Y. Y. Hu, "Partial nitrification to nitrite for treating ammonium-rich organic wastewater by immobilized biomass system," Bioresource Technology, vol. 100, no. 8, pp. 2341-2347, 2009.

[16] T. Yamamoto, K. Takaki, T. Koyama, and K. Furukawa, "Longterm stability of partial nitritation of swine wastewater digester liquor and its subsequent treatment by Anammox," Bioresource Technology, vol. 99, no. 14, pp. 6419-6425, 2008.

[17] H. Chen, S. Liu, F. Yang, Y. Xue, and T. Wang, "The development of simultaneous partial nitrification, ANAMMOX and denitrification (SNAD) process in a single reactor for nitrogen removal," Bioresource Technology, vol. 100, no. 4, pp. 1548-1554, 2009.

[18] A. Spagni and S. Marsili-Libelli, "Nitrogen removal via nitrite in a sequencing batch reactor treating sanitary landfill leachate," Bioresource Technology, vol. 100, no. 2, pp. 609-614, 2009.

[19] A. Manipura, J. R. Duncan, H. J. Roman, and J. E. Burgess, "Potential biological processes available for removal of nitrogenous compounds from metal industry wastewater," Process Safety and Environmental Protection, vol. 83, no. 5, pp. 472-480, 2005.

[20] K. Egli, C. Langer, H.-R. Siegrist, A. J. B. Zehnder, M. Wagner, and J. R. Van der Meer, "Community analysis of ammonia and nitrite oxidizers during start-up of nitritation reactors," Applied and Environmental Microbiology, vol. 69, no. 6, pp. 3213-3222, 2003.

[21] M. S. M. Jetten, M. Wagner, J. Fuerst, M. van Loosdrecht, G. Kuenen, and M. Strous, "Microbiology and application of the anaerobic ammonium oxidation ("anammox") process," Current Opinion in Biotechnology, vol. 12, no. 3, pp. 283-288, 2001. 

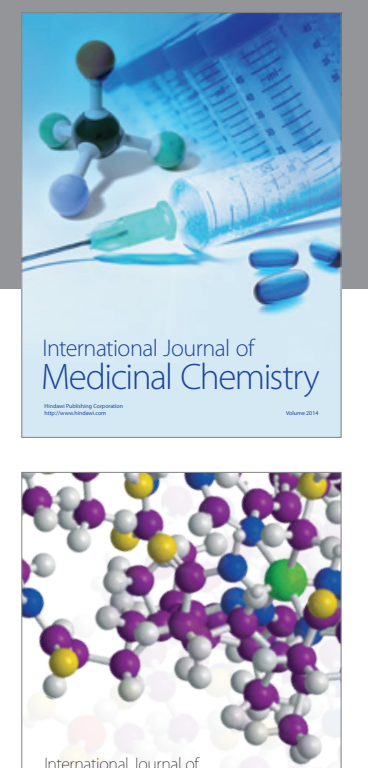

\section{Carbohydrate} Chemistry

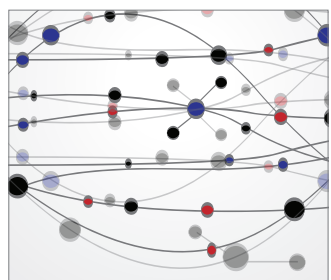

The Scientific World Journal
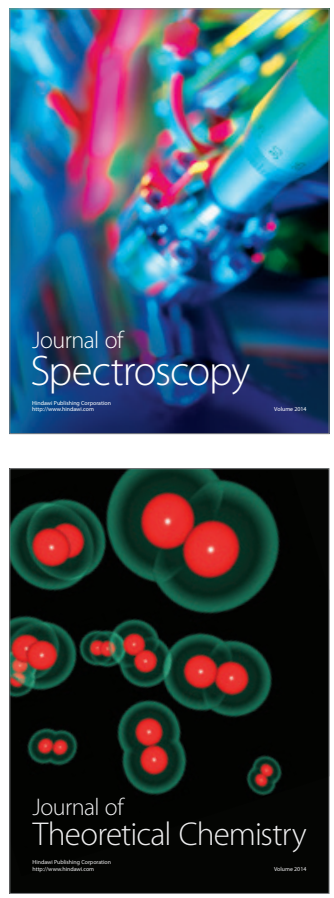
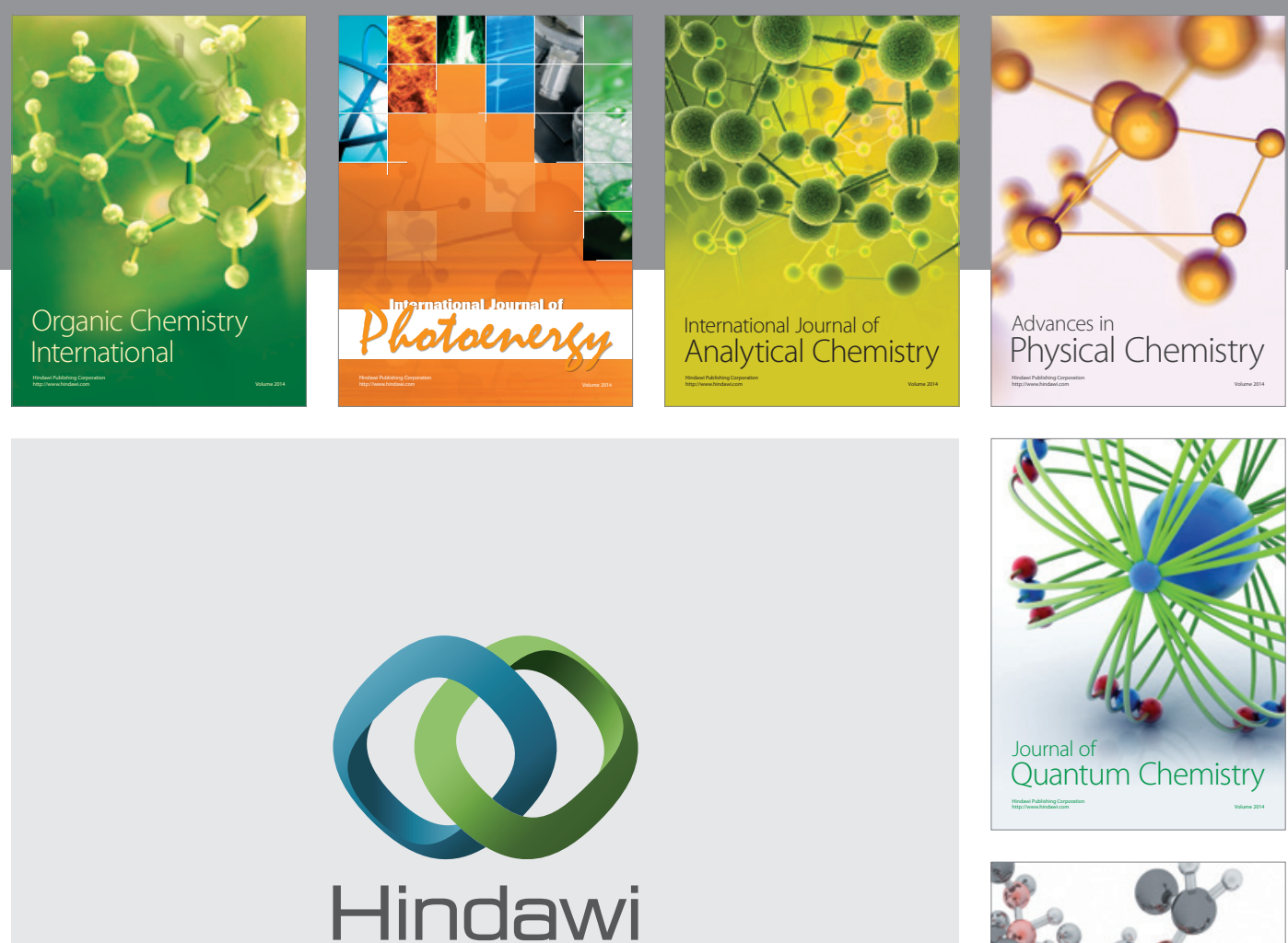

Submit your manuscripts at

http://www.hindawi.com

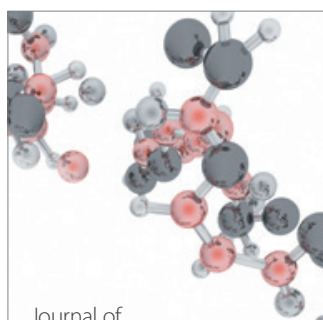

Analytical Methods

in Chemistry

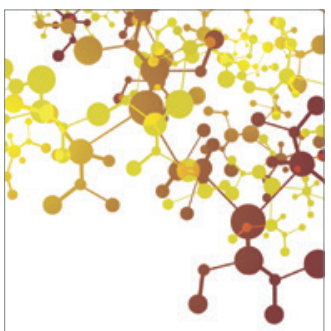

Journal of

Applied Chemistry

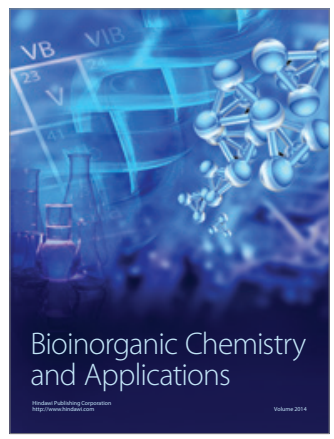

Inorganic Chemistry
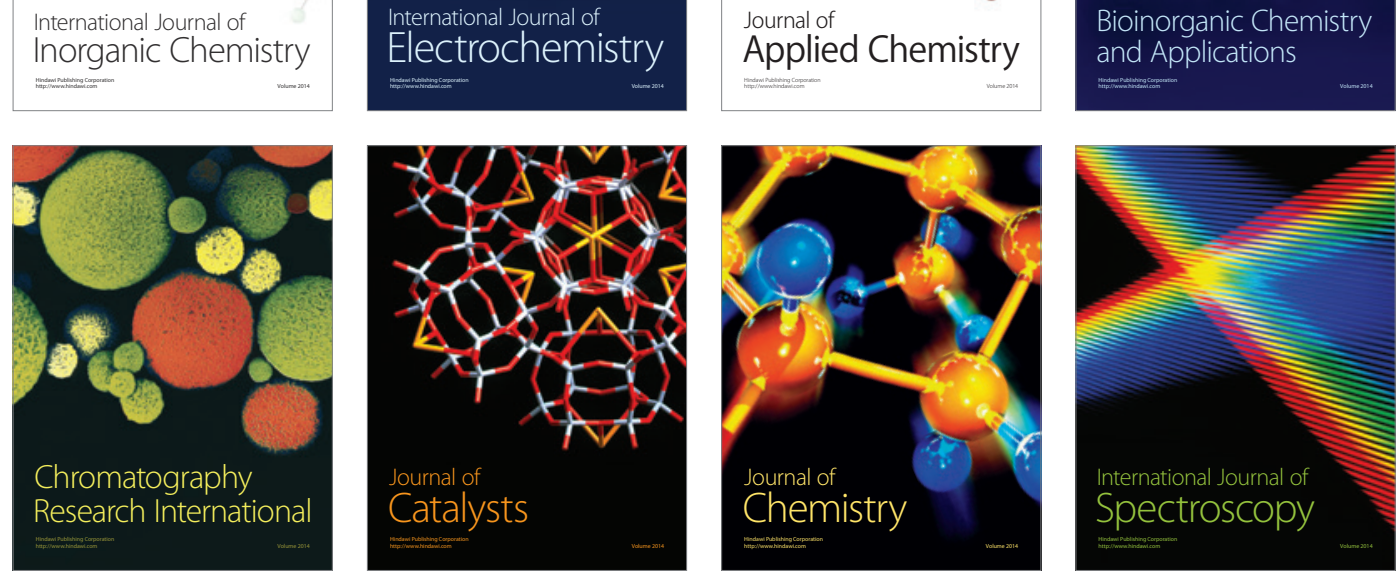